Marquette University Law School

Marquette Law Scholarly Commons

2020

The Impact of the Singapore Convention on the Development of Non-Adjudicative Forms of International Dispute Resolution

Andrea Kupfer Schneider

Follow this and additional works at: https://scholarship.law.marquette.edu/facpub

Part of the Law Commons

Publication Information

Andrea Schneider, The Impact of the Singapore Convention on the Development of NonAdjudicative Forms of International Dispute Resolution, 114 Am. Soc'y Int'I L. Proc. 123 (2020) 


\title{
The Impact of the Singapore Convention on the Development of Non- ADJudicative Forms of International Dispute Resolution
}

doi:10.1017/amp.2021.32

\author{
By Andrea Schneider*
}

The impact of the Singapore Convention might affect both state and companies' behaviors even more than encouraging mediation. We have had for a long time the phrase "bargaining in the shadow of the law," and then more recently, in particular when we look at international investment, it is bargaining in the shadow of international arbitration. ${ }^{2}$ We know that a dispute could end up in arbitration and therefore impact behaviors before that. I want us to think about what bargaining might look like in the shadow of mediation. ${ }^{3}$

* Professor of Law and Director of the Dispute Resolution Program, Marquette University Law School.

${ }^{1}$ Robert H. Mnookin \& Lewis Kornhauser, Bargaining in the Shadow of the Law: The Case of Divorce, 88 YALE L.J. (1979).

${ }^{2}$ Jill I. Gross, Bargaining in the (Murky) Shadow of Arbitration, 24 HaRV. NeGOT. L. ReV. 186 (2019); Jill I. Gross, Negotiating in the Shadow of Adhesive Arbitration, in The Negotiator's Desk Reference (Chris Honeyman \& Andrea Kupfer Schneider eds., 2017).

${ }^{3}$ Andrea Kupfer Schneider \& Nancy A. Welsh, Bargaining in the Shadow of Investor-State Mediation: How the Threat of Mediation Will Improve Conflict Management, Univ. Sт. Thомаs L.J. (forthcoming); Nancy A. Welsh \& Andrea K. Schneider, The Thoughtful Integration of Mediation into Bilateral Investment Treaty Arbitration, 18 HARV. Negot. L. REv. 71 (2013). 
Mediation is not going to establish law in the same way that arbitration and litigation have precedential value or persuasive value. But when countries and investors both know that mediation is the next process that they will take advantage of, we can consider what is the trickle-down effect, in terms of those conversations that are had between governments and investors as disputes arise.

\section{Concerns with Mediation}

I will start at the outset with some of the bad news. The Singapore Convention is obviously not going to alleviate the problems that have been tracked by the World Bank and others in terms of securing foreign direct investment. There will still be a political cost to settling disputes voluntarily. Whether it is for a particular agency or for a national government, the political cover that countries are able to use when they say they have been forced to pay out to an investor, perhaps against their will, is still not going to be provided in mediation.

The incentives for agencies in government could well be different as well between the national versus local level, or between national agencies with different portfolios, like customs versus investment. There are going to be different incentives for those agencies. Often, you are going to have state or local regulatory agencies, who are the ones actually driving the dispute, in particular by a regulation they have imposed. ${ }^{4}$ They are going to have a different incentives in terms of staying in power or demonstrating that they are taking care of their citizens, compared to the federal or national government that has, in fact, encouraged the investment in the first place.

Mediation will require coordination between those agencies promoting investment and those agencies that are regulating the investors. That coordination, in some ways, will be even more heightened in a mediation process where the real goal is to get everyone in the room to talk about what is happening on the regulatory side and the finance side, versus who in the legal department might be pursuing mediation before it hits arbitration.

Mediation, by itself, is not going to solve those problems. It may provide a better process for resolving these disputes. And the push to think about various processes may help manage those differing incentives in terms of how different agencies, government officials, both local and national, get rewarded for effectiveness in their behavior in promoting and monitoring foreign direct investment. ${ }^{5}$

\section{Socializing Mediation as Normal}

The good news, however, is that we can "socialize companies to use mediation." The Singapore Convention normalizes mediation and socializes both companies and governments to use mediation. This socialization then gives us far more ability to be creative in non-consensual dispute resolution mechanisms even before we get to mediation. As others have noted on the panel already, it is not just lawyers that we are talking about, who may have gone to law schools rife with alternative dispute resolution classes and mediation clinics. It is really a question of how we are socializing our clients, our government officials, and everyone in the understanding of these new process possibilities. There are four points regarding the impact of normalizing mediation.

\footnotetext{
${ }^{4}$ Roberto Echandi, The Debate on Treaty-Based Investor-State Dispute Settlement: Empirical Evidence (1987 2017) and Policy Implications, 34 ICSID REV. 32 (2019).

${ }^{5}$ See Susan D. Franck, Using Investor-State Mediation Rules to Promote Conflict Management: An Introductory Guide, 29 ICSID R. - FoREIGN INV. L.J. 66, 70 (2014).

${ }^{6}$ Mark Califano remarks, ASIL Panel on The Singapore Convention on Mediation and the Future of Appropriate Dispute Resolution (June 9, 2020).
} 


\section{A. Coordinating Interests}

First, how do we coordinate conversations among agencies at the federal and state level, at the national and local level, and how do we have conversations about how countries are protecting and promoting investment? How do countries both promote and regulate? What we see is that whoever is responsible for promoting is not necessarily the one following up after there has been some problematic regulation that is making the investor unhappy. If mediation is able to build and socialize those conversations, that is a huge advantage.

\section{B. Stakeholder Identification}

Second, how do we think about communication between the investor and the applicable agency? When we think about mediation, we have to think strategically about who is at the table. Getting everyone to the table is important - considering the stakeholders who need to be there will demonstrate the importance of having a lot of different players at the table. ${ }^{7}$ To the extent mediation really starts to be a model of the importance of getting everybody at the table-investors at different levels and the government agencies at different levels - it may well help identify who we talk to, not only in the mediation, but the next time around even sooner. If stakeholders now know, "Oh, there were these five people that all had to be in the room when I mediated this particular problem, let me pick up the phone the moment there is a dispute, because now I know them. I have seen them on zoom, I have seen them in the room, let me reach out." That identification of all those multiple parties and interests could move those dispute resolutions earlier in the process. In the World Bank studies that have looked at how we effectively keep investment and minimize disputes, it is about that early intervention. ${ }^{8}$

\section{Early Intervention}

The third point to consider is these early processes. The strategic investment response mechanisms, as the World Bank calls them, or consensual dispute resolution mechanisms, can be successful. These interactions, earlier in the process, enable the investors and all the government players to get together sooner, long before this is something that is filed in arbitration. ${ }^{9}$ We know is that once it is filed, the investor often has decided to withdraw. Getting that investment back is far harder than keeping it in the first place. Early dispute resolution mechanisms can serve everybody's interest in terms of flagging that dispute and flagging the appropriate people to resolve it and keep that investment in the country. ${ }^{10}$

\section{Access to Justice}

Finally, we have talked over the years in terms of access to justice and countries' differing abilities to have skilled lawyers involved in the arbitration and how much it costs to go through

\footnotetext{
${ }^{7}$ ISDS Mediation Working Group, Unlocking Value Through Stakeholder Engagement: New Forms to Resolve InvestorState Disputes, 2020 ISDS Mediation Working Group Report 6 (2020), at https://www.imimediation.org/2020/06/18/ harvard-investor-state-mediation-report.

${ }^{8}$ World Bank Group, Retention and Expansion of Foreign Direct Investment: Political Risk and Policy RESPONSES (2019).

${ }^{9}$ Mariana Hernandez Crespo G., A New Chapter in Natural Resource-Seeking Investment: Using Shared Decisions System Design ("SDSD") to Strengthen Investor-State and Community Relationships, 18 CARdozo J. Conflict ReS. 551 (2016).

${ }^{10}$ WORLD BANK Group, supra note 8.
} 
arbitration. Mediation, and even earlier intervention, could be a huge cost savings, again, by getting more people involved early on. Access to justice can continue to be trumpeted for countries across the globe, in terms of how we keep investments and the lessons we are learning from that earlier intervention.

\section{CONCLUSION}

Roberto Echandi has referred to this early intervention as divorce therapy between companies and countries. ${ }^{11}$ It is much easier to get that therapy early in the marriage than it is once you have filed for divorce papers. Here too, if making mediation normal can help us move interventions earlier by virtue of identifying who needs to be there and normalizing creative processes, countries will be more likely to retain investment and save relationships.

\footnotetext{
${ }^{11}$ Roberto Echandi, Remarks at St. Thomas University Law School Symposium (Feb. 21, 2020); see also Roberto Echandi \& Priyanka Kher, Can International Investor-State Disputes Be Prevented? Empirical Evidence from Settlements in ICSID Arbitration, 29 ICSID REv. 41 (2014).
} 